\title{
INTERNALISASI NILAI-NILAI PENDIDIKAN KARAKTER PADA TRADISI MAGIBUNG
}

\author{
I Nengah Agus Tripayana', Nastiti Mufidah' ${ }^{2}$, Nurlaili Handayani ${ }^{3}$, Basyariah $^{4}$ \\ Universitas Mataram $^{1}$, IAIN Ponorogo ${ }^{2}$, Universitas Mataram ${ }^{3,4}$ \\ tripayanaagus@unram.ac.id; nastiti@iainponorogo.ac.id; handayani@unram.ac.id; \\ basyariah@unram.ac.id
}

\begin{abstract}
ABSTRAK
Penelitian ini dilakukan untuk mengeksplorasi tradisi magibung sebagai sarana belajar karakter bagi masyarakat. Agar memperoleh gambaran secara holistic, penelitan ini menggunakan studi deskriptif, dengan mengamati tradisi magibung yang ada diDesa Pakraman Seraya, Kecamatan Karangasem, Kabupaten Karangasem, Provinsi Bali. Penelitian ini diperoleh dengan menggunakan analisis deskriptif kualitatif menggunakan teknik triangulasi, dengan melakukan tiga langkah, yaitu: reduksi data, penyajian data dan penarikan kesimpulan/verifikasi. Adapun subjek dalam penelitian ini adalah (1)Tokoh-tokoh senior (panglingsir) masyarakat Desa Pakraman Seraya, (2) BendesaAdat Desa Pakraman Seraya, (3) Pemerintahan adat Desa Pakraman Seraya, (4) Pemerintah Dinas setempat, (5) Pemuda Desa Pakraman Seraya, (6) Tokoh masyarakat, (7) Masyarakat Desa Pakraman Seraya yang dapat memberikan informasi mengenai fokus penelitian yang akan di teliti. Hasil penelitian menunjukan bahwa tradisi magibung mampu menginternalisasi nilai-nilai karakter di lingkungan masyarakat, seperti; karakter religius, kerjasama (gotong-royong), mandiri, jujur, disiplin serta peduli.
\end{abstract}

Kata Kunci: Pendidikan Karakter; magibung; tradisi

\section{ABSTRACT}

This research was conducted to be explored as a means of learning character for the community. In order to obtain a holistic picture, this research uses a descriptive study, with the maintenance of the magibung tradition in Pakraman Seraya Village, Karangasem District, Karangasem Regency, Bali Province. This research was obtained by using a qualitative descriptive analysis using triangulation techniques, by doing three, namely: data reduction, data presentation and drawing steps / levers. The subjects in this study were (1) senior figures (panglingsir) of the Pakraman Seraya Village community, (2) Bendesa Adat Pakraman Seraya Village, (3) Pakraman Seraya Village customary administration, (4) Local Government Service, (5) Village Youth Pakraman Seraya, (6) community leaders, (7) Pakraman Seraya Village community who can provide information about the focus of the research to be studied. The results showed that the magibung tradition was able to internalize character values in the community, such as; religious character, cooperation (mutual assistance), independent, honest, disciplined and caring.

Keywords: Character Education; magibung; tradition 


\section{A. PENDAHULUAN}

Beberapa dekade belakangan ini, muncul kesadaran dari banyak pihak, tentang pentingnya menggali nilai-nilai dalam tradisi lisan sebagai sumber belajar, khususnya pembelajaran karakter. Hal ini terjadi ketika sumber-sumber pengetahuan modern yang umumnya diperoleh dari kajian akademis dan diambil dari sumber tertulis, sering kali tidak mampu menyuguhkan solusi terhadap fenomena terhadap masalah yang terjadi dilingkungan masyarakat. Hal ini didukung oleh kondisi sebagian lembaga pendidikan formal yang selalu berpatokan pada kajian ilmu pengetahuan yang bersumber pada literatur tertulis.

Sementara itu, kajian tidak tertulis kurang mendapatkan perhatian sebagai sumber kajian ilmu pengetahuan. Pada dasarnya, penyelenggaraan proses pendidikan, terutama pendidikan formal selalu berkaitan erat dengan aspek lingkungan, sebagai tempat penyelenggaraan proses pendidikan. Antara proses pendidikan dengan aspek lingkungan atau masyarakat tidak dapat dipisahkan satu sama lain, dalam hal ini keduanya saling memberi pengaruh satu sama lain. Terlebih lagi lingkungan masyarakat sebagai embrio, tempat pengaplikasian serta berkembangnya proses pendidikan dan ilmu pengetahuan. Sebagai contoh, karakteristik pendidikan masyarakat pesisir pantai akanberbeda dengan pendidikan masyaraakat didaerah perkotaan atau pedesaan. Hal ini dikarenakan adanya perbedaan budaya dan tradisi yang ada dimasyarakat.

Oleh karenanya, sangat penting untuk menggali nilai-nilai pada suatu tradisi yang dipelihara oleh masyarakat agar dapat diadopsi dan dibelajarkan kepada peserta didik dalam proses pendidikan (formal, informal maupun non-formal). Sebagai makhluk sosial, masyarakat terbiasa untuk hidup berkelompok. Tiap kelompok masyarakat memiliki adat dan tradisi yang berbeda dengan kelompok masyarakat lainnya. Adat dan tradisi ini menjadi ciri khas dan penanda yang membedakan antara suatu kelompok masyarakat dengan yang lain. Adat dan tradisi yang ada pada saat ini,tidak muncul begitu saja, tetapi lahir dan diwariskan oleh nenek moyang mereka sejak bertahun-tahun yang lalu. Tradisi ini kemudian dilestarikan dari generasi ke generasi melewati berbagaizaman. 
Tradisi yang tidak sesuai dengan pandangan hidup masyarakat dan perubahan zaman, berangsur-angsur akan ditinggalkan oleh masyarakatnya,sampai akhirnya punah. Sebaliknya, tradisi yang memiliki kesadaran moral, norma, dan nilai serta legitimasi terhadap pandangan hidup dan perkembangan zaman, akan tetap dipertahankan dan terus diwariskan ke generasi selanjutnya. Tradisi yang ada pada suatu kelompok masyarakat mencerminkan karakter atau kepribadian masyarakat itu sendiri. Oleh karenanya,setiap kelompok masyarakat disertai dengan bentuk tradisi yang berbeda antara satu samalain, sebagai cerminan karakter dan kepribadian serta nilai yang dimiliki kelompok masyarakat tersebut.

Berdasarkan KBBI (Kamus Besar Bahasa Indonesia) tradisi mempunyai artian sebagai segala sesuatu yang dianggap merupakan kebiasaan atau merupakan adat istiadat yang turun temurun dilakukan pada suatu tempat tertentu. Sedangkan dalam bahasa latin, tradisi (tradition) mengandung artian "diteruskan" atau berarti suatu hal yang telah dilakukan sejak lama sehingga telah menjadikannya sebagai bagian dari kehidupan masyarakat tersebut seperti waktu, kebudayaan maupun agama.

Piotr Sztompka (2004) menyatakan bahwa keberadaan tradisi memiliki beberapa fungsi dimana pendapatnya menguatkan pandangan bahwa adat dan tradisi yang masih dipertahankan dikarenakan adanya nilai-nilai luhur yang terkandung dalam tradisi tersebut, yang dapat dipedomani oleh masyarakat dalam kehidupan sehari-hari. Keberadaan nilai-nilai dalam tradisi tersebut diangap lebih baik daripada nilai-nilai modern yang cenderung bertentangan dengan nilai-nilai yang diwariskan dalam adat dan tradisi yang ada. Selain itu adat dan tradisi tersebutdiyakini sebagaisimbol identitas kolektif, sehingga harus tetap dipertahankan dan diwariskan secara terus menerus ke generasi selanjutnya.

Kenyataan tersebut menarik minat penulis untuk menggali nilai-nilai karakter pada tradisi megibung sebagai wahana pendidikan karakter.Magibung merupakan suatu tradisi yang ada di Desa Pakraman Seraya, Karangasem, Bali. Tradisi ini sudah berlangsung selama ratusan tahun, dan masih tetap dipertahankan oleh masyarakat setempat sampai dengan saat ini (Maris, 1994). Kebiasaan makan secara berkelompok ini membuat masyarakat hidup secara egaliter. Berbagai nilai 
karakter yang ada dalam tradisi magibung tersebut, sejatinya dapat digali untuk diaplikasikandi dunia pendidikan (formal, informal maupun non formal).Oleh karenanya, sangatlah penting bagi kita untuk dapat mengkristalisasi kembali berbagai nilaikarakter yang terkandung dalam tradisi tersebut kedalam dunia pendidikan secara tepat dan benar.

Pendidikan karakter bukanlah wacana baru dalam dunia pendidikan di Indonesia. Jauh sebelum Bangsa Indonesia bediri, model pendidikan yang menekankan pada norma dan moral dapat kita lihat pada epos Ramayana karya Bagawan Walmika dan epos Mahabhrata karya Bagawan Biasa. Sedangkan pada era pra-kemerdekaan, beberapa nama pahlawan yang tersohor dalam dunia pendidikan seperti; Ki Hajar Dewantara, R.A Kartini, dan Moh. Natsir sangat konsen terhadap penanaman nilai-nilai karakter dalam dunia pendidikan,nilai karakter dijadikan sebagai modal pembentukan kepribadian dan jati diri Bangsa Indonesia.

Lembaga pendidikan, khususnya pendidikan formal, memiliki tugas yang sangat penting, diantaranya; mentransmisi pengetahuan (transfer of knowledge), mentransmisi budaya (transfer of culture), sertamentransmisi nilai (transfer of value). Sehingga oleh Nugroho (2016) pendidikan dipahami sebagai suatu proses transformasi berbagai nilai dalam rangka membentuk kepribadian individu. Oleh karenanya lembaga pendidikan tidak hanya bertugas melaksanakan transfer ilmu semata, namun yang lebih penting adalah kemampuan lembaga pendidikan dalam membentuk karakter masyarakatnya. Pembentukan karakter, dilakukan oleh pendidik kepada para peserta didik melalui kristalisasi nilai-nilai tradisi yang ada didalam maupun diluar lembaga pendidikan.Berdasarkan uraian yang dipaparkan sebelumnya, penulis tertarik untuk meneliti nilai-nilai karakter yang terkandung dalamtradisi magibung sebagai wahana pendidikan karakter.

\section{Tradisi Magibung}

Secara etimologis magibung berasal dari kata dasar magi dan buwung, magi berarti kegiatan membagi-bagikan, sedangkan buwung berarti batal. Dari arti kata tersebut dapat diartikan bahwa magibung berarti "batal membagi". Yaitu makanan dalam satu wadah yang batal dibagi, tapi dimakan secara bersama-sama oleh 
kelompok-kelompok kecil. Tradisi magibung ini telahdilaksanakan sejak lama di Kabupaten Karangasem, Bali. Pada masa itu masih berbentuk kerajaan, yaitumasa pemerintahan I Gusti Anglurah Ketut Karangasem, dan masih dipertahankan hingga saat ini (Tripayana, 2016).

Maris (1994) menegaskan, tradisi magibung merupakan suatu tata cara santap atau makan yang sudah melembaga sejak jaman dahulu dan sampai saat sekarang ini masih terpelihara dengan baik dan ajeg. Tradisi magibung ini merupakan warisan nenek moyang zaman dahulu yang masih tetap terpelihara sampai dengan saat ini yang telah melalui beberapa generasi.Penjelasan mengenai asal usul tradisi magibung inijugadapat ditemukan dalam Lontar Dwi Jendra Tattwa (seken, 2014:48) yang menyebutkan:

"Wus amuja, Ida katuran bojan. Sampun usan aneda bojana.

Anyarik sang putra kabeh.

Lor wetan kidul kulon".

Kalimat diatas berarti "Setelah selesai memuja, sang pendeta dihaturi hidangan santapan. Maka empat orang putranya disuruh meneruskan menikmati sisa hidangan, ada yang menghadap utara, timur, selatan dan barat". Sementara dilembar berikutnya disebutkan sebagai berikut:

Sampuning wus amuja

Ida katuran bojana

Sampuning wus aneda bojana

Inutus putara ira meneda bojana kenem diri atunggal wadah

Kalimat diatas bermakna "Setelah selesai melaksanakan prosesi pememujaan, sang pendeta diberi hidangan berupa makanan. Setelah beliau selesai makan, maka dipanggilah ke enam orang putranya, untuk makan bersamasama dalam satu tempat hidangan. Kalimat "dipanggilah ke enam orang putranya untuk makan bersama dalam hidangan" dapat dimaknai sebagai magibung.

Tradisimagibungdilaksanakan pada saat warga menggelar upacara adat atau upacara keagamaan. Seperti; upacara pitra yadnya (upacara pemujaan para leluhur), upacara manusia yadnya, (upacara keagamaan yang ditujukan untuk keselamatan manusia) seperti; nyolasin (upacara untuk bayi yang sudah berumur 
sebelas hari) otonan (upacara untuk bayi yang berumur tiga bulan), mepandes (upacara potong gigi), acara pernikahan, dan upacara dewa yadnya (upacara yang ditujukan kepada para Dewa), seperti; piodalan (upacara persembahan yang dilakukan di Pura), pemelaspasan(yaitu upacara penyuciantempat ibadah).

Magibung memiliki aturan tidak tertulis, namun sangat ditaati oleh masyarakat. Apabila dilanggar akanmendapat sanksi sosial, seperti; ditegur, dicemooh, dianggap tidak sopan, sampai dikucilkan dari pergaulan. Beberapa aturan tersebut, misalnya; tidak boleh sendawa, kentut atau mengobrol saat makan. Makan harus dilakukan secara bersama-sama dan serentak disemua kelompok. Tidak dibolehkan menggunakan sendok atau garpu, tapi langsung menggunakan tangan. Sisa makanan tidak boleh ditaruh kembali ke wadah, agar tidak dimakan oleh peserta lain. Tidak dibolehkan mengambil nasi atau lauk orang lain, tiap kelompok memiliki ketua kelompok, yang bertugas mengatur jalannya proses magibung. Para peserta tidak diperkenankan berdiri atau meninggalkan arena magibung, sebelum acara magibung selesai, kecuali dalam keadaan darurat.

Tradisi magibung adalah salah satu bentuk dari kearifan lokal yang penuh dengan berbagai nilai dan menjadi pembentuk karakter masyarakat Bali. Magibung tidak membeda-bedakan berbagai status sosial maupun status ekonomi, berbagai kasta ataupun catur warna. Anggota satu sela, misalnya, boleh diikuti oleh siapapun baik pejabat, tokoh masyarakat, tokoh agama, atau bahkan masyarakat biasa. Semua membaur bersama-sama, duduk melingkar menghadap bhoga (hidangan). Semua peserta makan dengan hikmat, penuh rasa kekeluargaan.

Kebiasaan gotong royong dalam magibung, juga diaplikasi oleh masyarakat pada kegiatan lainnya dimasyarakat. Masyarakat setempat sangat sering melakukan pekerjaan secara bersama-sama tanpa meminta gaji atau imbalan. Hal ini mereka aplikasikan pada saat membangun jalan, mendirikan rumah, membersihkan lingkungan, bercocok tanam, beternak dan sebagainya. Satu sama lain saling menawarkan diri secara sukarela menawarkan bantuan untuk menyelesaikan pekerjaan orang lain. Selain itu, juga berpengaruh terhadap 
sikap dan prilaku masyarakat. Rasa solidaritas dan kekeluargaan sangat kuat terjalin diantara masyarakat, meskipun diantara mereka tidak ada hubungan kekerabatan sekalipun. Mereka tidak segan untuk membantu warga lain yang sedang mengalami bencana atau kesusahan. Kondisi ini memungkinkan terjalin hubungan yang harmonis antar anggota masyarakat.

\section{Nilai-nilai Pendidikan Karakter}

Pendidikan juga dimaknai sebagai suatu kondisi yang dapat mengubah nilai seseorang dan dapat mempengaruhi perubahan dalam perilaku seseorang (Istingsih, 2016:34). Sementara itu, karakter merupakan nilai-nilai yang unik dan baik (tahu nilai kebaikan, mau berbuat baik, dan nyata berkehidupan baik) yang terpatri dalam diri dan terejawantahkan dalam perilaku.Karakter secara koheren memancar dari hasil olah pikir, olah hati, olah rasa dan karsa, serta olahraga seseorang atau sekelompok orang (Mulyasa, 2014).

Sejalan dengan pendapat di atas oleh Lickona (1991:51)diuraikan bahwakarakter dimaknai sebagaiwatak batin guna mengartikan situasi atau kondisi dengan carayang baik secara moral.Selain itu Lickona pun menguraikan bahwa terdapat 3 bagian dalam karakter yang saling terkait yakni, moral perasaan, moral pengetahuan serta moral perilaku. Dalam hal ini karakter baik dapat dibentuk melalui 3 tahapan yakni mengetahui, menginginkan, selanjutnya melakukan kebiasaan yang baik. Tahapan kebiasaan yang baik yakni kebiasaan yang dileburkan di dalam kebiasaan dalam hati, pikiran, sertadalam tindakannya. Di sisi lain, Breedemeier \& Shields (2019:203) memaknai karakter sebagai emosi, pemahaman serta prilaku tertentu yang memunculkan kecenderungan prilaku yang dilakukan dalam situasi atau kondisi serupa.

Dalam karakter seseorang terdapat tujuh nilai dasar atau core values Emotional Spiritual Quetient (ESQ) yaitu: jujur, disiplin, tanggung jawab, peduli, adil, kerjasama, serta Visioner. Ketujuh nilai dasar tersebut membangun suatu kesatuan dan keutuhan dalam membangun watak (Ginandjar, 2001:321).Karakter seseorang dapat dibentuk melalui proses pembelajaran yang disebut dengan pendidikan karakter. Dalam proses pembelajarannya pendidikan karakter tidak hanya dapat dilakukan di lingkungan persekolahan saja, namun jugadapat 
dilakukan melalui transformasi budaya, penerapan aturan, berbagai macam acara dan upacara untuk memberikan contoh yang mendukung kebiasaan yang baik bagi siswa (Marini, Safitri, \& Muda, 2018: 275).Seperti contoh karakter kepedulian merupakan salah satu karakter yang dapat dibentuk dan dikembangkan melalui Program Jam Wajib Belajar yang diterapkan di masyarakat (Mufidah, 2016:42). Sejalan dengan hal tersebut, Saidek, Islami, \& Abdoludin (2016: 158) mengatakan bahwa di Indonesia, karakter dibangun di atas berbagai nilai-nilai yang berlaku dalam budaya warga negara Indonesia. Hal ini berarti bahwa karakter Bangsa Indonesia dibelajarkan melalui berbagai macam media serta merupakan gabungan berbagai nilai yang ada dalam berbagai macam budaya.

Berdasarkan berbagai uraian tersebut dapatlah disimpulkan bahwa pendidikan karakter merupakan upaya sadar serta terencana guna membentuk para peserta didik, selain cerdas juga memiliki akhlak dan prilaku yang baik, serta mampu diaplikasikan dalam kehidupannya. Pendidikan karakter berkaitan dengan menanamkan kebiasaan berperilaku baik sesuai dengan norma yang ada dimasyarakat. Mendidik anak-anak terutama pembentukan karakter tidak melulu dapat dilakukan didalam kelas, pendidikan karakter tersebut juga dapat diaplikasikan dalam berbagai aspek yang ada dimasyarakat, salah satunya melalui internalisasi nilai yang terdapat dalam tradisi yang ada dimasyarakat. Pendidikan karakter bukan hanya berkaitan dengan definisi atau pembelajaran teoritis, melainkan suatu prilaku yang nyata yang ditauladankan oleh para pendidik dengan menggali nilai-nilai luhur yang hidup dan berkembang dimasyarakat.

\section{B. METODE PENELITIAN}

Pendekatan kualitatif dengan metode deskriptif diguankan dalam penelitian ini. Penelitian dilakukan di Desa Pakraman Seraya, Kecamatan Karangasem, Kabupaten Karangasem, Provinsi Bali.Adapun subjek dalam penelitian ini dipilih dengan teknik pusposive sampling, yakni mereka yang mampu memberikan informsi yang dibutuhkan peneliti, antara lain: (1), Tokoh masyarakat (panglingsir); (2) tetua adat (bendesa); (3) budayawan; (4) pemuda desa (trunatruni); (5) masyarakat setempat (karma desa). Pengambilan data dilakukan 
melalui observasi, wawancara, dan partisipan.Terdapat tigaalur kegiatanyang dilakukan guna menganalisis data dalam penelitian ini yang dilakukan secara bersamaan yakni: reduksi data, penyajian data, penarikan kesimpulan/verifikasi,dimana keabsahan data diuji dengan teknik triangulasi(Miles dan Huberman, 1992).

\section{HASIL DAN PEMBAHASAN}

Rahasia eksistensi suatu tradisi yang berlangsung selama puluhan bahkan ratusan tahun, karena adanya nilai-nilai luhur yang dapat dipedomani oleh masyarakat dari generasi ke generasi. Nilai-nilai tersebut bersifat fleksibel dan dapat menyesuaikan dengan perubahan zaman. Dalam tradisi magibung terkandung nilai-nilai karakter yang dapat dijadikan pedoman oleh masyarakat, diantaranya:

\section{Karakter Religius}

Karakter religius tercermin pada setiap tahapan prosesmagibung. Baik pada proses persiapan, proses pelaksanaan maupun pasca magibung. Pada tahap persiapan, didahului dengan prosesi ngejot, yaitu prosesi menghaturkan sesaji, berupa makanan, lauk pauk dan sayurkepada leluhur dan para Dewa. Sesaji ini dihaturkan di sanggah (tempat persembahyangan), sebagai wujud ungkapan terimakasih kepada para dewa dan leluhur atas segala rejeki dan karunia yang diberikan.Prosesi ngejot wajib dilaksanakan sebelum magibung. Hal ini sebagai bentuk penghormatan manusia kepada para dewa dan leluhur, yang telah memberikan rizki dan karunia kepada umat manusia. Setelah proses ngejot ini selesai,barulah magibung boleh dilaksanakan.

Pada prosesi pemotongan hewan diawali dengan pembacaan doa dan pemberian sesajen untuk mendoakan agar roh hewan tersebut naik menuju tingkatan yang lebih tinggi (sesuai dengan keyakinan akan adanya reinkarnasi menurut Hindu). Setiap sela (kelompok makan) terdiri sembilan orang. Jumlah sembilan sebagai simbol, Dewata Nawa Sanga, yaitu sembilan dewa penjaga arah mata angin menurut Hindu. Para peserta magibung yang berjumlah delapan akan duduk sesuai dengan arah mata angin, yakni menghadap barat 
daya, barat, barat laut, timur, timur laut, tenggara, utara dan selatan. Sedangkan gibungan yang ditaruh ditengah lingkaran sebagai pusatnya.

\section{Kerjasama (Gotong Royong)}

Prosesmagibung sangat kental dengan nuansa gotong royong. Tanpa adanya gotong royong, mustahil magibung dapat dilaksanakan. Mulai dari persiapan tempat, mengumpulkan bahan makanan, hingga mengolah bahan makanan juga harus dilakukan secara bersama sama. Bahkan untuk makan pun harus bersama-sama, sesuai dengan konsepnya yaitu makan bersama. Kebiasaan ini membentuk masyarakat menjadi egaliter.

Nilai kemanusiaan tercermin di setiap proses pelaksanaan dan persiapan magibung. Pada saat magibung dilaksanakan setiap orang akan mencari pasangan yang akan diajak magibung. Satu gibungan (makanan yang akan dipakai magibung) dimakan oleh enam orang, sehingga masing-masing peserta akan mencari enam orang untuk diajak magibung. Disini terlihat adanya nilai keadilan, dimana orang yang diajak magibung diperlakukan sama. Nilai keadilan lainnya dapat terlihat dari pemilihan ketua magibung. ketua yang dipilih berdasarkan musyawarah mufakat tanpa melihat latar belakang ekonomi maupun jabatan. Semua orang berhak untuk dipilih dan memilih. Selain itu apabila ada peserta yang melanggar aturan-aturan magibung, seperti mendahului makan atau mendahului bangun dari tempat duduk, bersendawa saat makan, mengambil bagian orang lain akan diberikan sanksi teguran maupun sanksi sosial lainnya, tanpa pengecualain. Setiap peserta yang melakukan kesalahan atau pelanggaran yang dilakukan secara sengaja akanmendapatkan sanksi dari peminpin atau ketua kelompok magibung.

Tahapan proses persiapannya. Semua calon peserta magibung bekerja dengan sungguh-sungguh tanpa terkecuali. Mereka bekerja tanpa dikomando. Masing-masing orang sudah sadar akan tugas dan kewajibanya masing-masing. Masing-masing orang akan membagi diri, ada yang bekerja memasak nasi, memasak sayur, membuat sate, membakar sate menyiapkan bumbu, memotong daging dan lain sebagainya. Satu pekerjaan yang paling sulit dalam magibung, sehingga membutuhkan keahlian khusus yaitu meracik bahan gibungan. Orang 
yang membuat dan meracik gibungan biasa disebut tukang ebat, sedangkan proses membuat gibungan disebut mebat.

\section{Mandiri}

Setiap peserta dilatih agar dapat bertanggung jawab terhadapkewajiban serta tugasnya. Proses magibung akanterganggu apabila ada peserta yang tidak melakukan tugasnya,seperti contoh yang sederhana adalah ketika peserta yang telah memperoleh tanggung jawab untuk menanak nasi, namun dia tidak menyelesaikan kewajibannya tersebut, maka hal tersebut akan mengganggu proses magibung. Oleh karenanya sangatlah penting masing-masing peserta untuk secara mandiri dan bertanggung jawab dalam melaksanakan tanggung jawabnya agar tidak mengecewakan peserta magibung lainnya. Pada umumnya para peserta yang tidak dapat melaksanakan atau menyelesaikan kewajiban yang telah diberikan maka diberikan sanksi oleh masyarakat berupa teguran, dikucilkan dari pergaulan, mnjadi bahan omongan dan lain sebagainya.

\section{Jujur}

Karakter kejujuran yang tercermin dalam tradisi magibung dapat dilihat saat proses persiapan dan pelaksanaan magibung. Pada saat proses persiapan, terdapat aturan tidak tertulis kepada para peserta untuk tidak menyantap makanan atau bahan makanan, kecuali hanya pada saat prosesi magibung. Hal ini membutuhkan kejujuran dari semua orang karena tidak ada yang akan mengawasi. Saknsinya pun tidak ada, hanya mengandalkan kejujuran diri masing-masing. Pada proses pelaksanaan magibung, pembagian lauk harus dibagi secara merata dan adil. Dalam hal ini sangat dibutuhkan adanya kejujuran dari masing-masing orang untuk mengambil lauk sesuai pembagiannya.

\section{Disiplin}

Tradisi magibung penuh dengan aturan yang ketat, selain aturan yang ketat sanksi bagi yang melanggar juga ditakuti masyarakat. sanksi yang ada umumnya bukan berupa materi, melainkan sanksi sosial, seperti rasa malu karena dicemooh, dikucilkan dari pergaulan, sampai teguran langsung. Para peserta magibung biasanya akan datang tepat waktu yakni mulai pukul lima 
pagi, para peserta magibung akan malu jika mereka datang terlambat. Setiap peserta datang dengan berpakain yang rapid dan bersih. Pada umumnya pakaian yang digunakan adalah pakaian adat Bali dengan menggunakan kain kamben, senteng dan udeng. Penggunaan pakaian adat karena pelaksanaan magibung berbarengan dengan upacara keagamaan.Dalam pelaksanaan magibung juga terdapat banyak aturan, misalnya; tidak boleh makan sambil berbicara, tidak boleh sendawa atau melakukan hal-hal yang jorok dan kotor, tidak boleh mengambil makan orang lain, tidak boleh menaruh sisa makanan di wadah, tidak boleh mendahului, memulai dan berhenti magibung harus bersamaan, dan aturan lainnya. Semua aturan tidak tertulis tersebut melatih setiap orang untuk menjadi pribadi yang disiplin.

\section{Peduli}

Magibung mendidik masyarakat untuk hidup secara egaliter. Secara kodrati manusia tercipta sebagai makhluk sosial dimana manusia tak akan dapat hidup tanpa bantuan orang lain. Magibung dapat memupuk kepekaan masyarakat untuk selalu peduli terhadap sesama. Setiap orang akan saling bertegur sapa, satu sama lain. Saling menawarkan minuman dan menanyakan kabar. Selain itu, ketika prosesi magibung akan berlangsung, para warga akan saling mempersilakan untuk makan terlebih dahulu kemudian melayani segala keperluan yang dibutuhkan. Kegiatan ini dilaksankan secara bergiliran,setelah selesaimagibung selesai akan bertugas melayani yang belum magibung.

\section{KESIMPULAN}

Berdasarkanhasil penelitian yang dilakukan maka dapat disimpulkan bahwa tradisi magibung merupakan suatu simbol keharmonisan hubungan antara manusia dengan manusia, manusia dengan alam, serta manusia dengan Tuhannya. Keharmonisan tersebut dapat terlihat dari proses persiapan pelaksanaan magibung sampai dengan selesainya magibung. Dimana dalam proses pelaksanakannya magibung dilakukan secara bersama-sama, semua orang yang hadir berbaur menjadi satu tanpa mempermasalahkan latar belakang sosial, ras dan agama.Lebih lanjut terdapat berbagai nilai karakteryang bersifat fleksibel dan dapat 
menyesuaikan dengan perubahan zaman dalam tradisi magibung. Nilai karakter yang terkandung dalam tradisi magibungyakni;religius, kerjasama (gotongroyong), mandiri, jujur, disiplin serta peduli.

\section{REFERENCES}

Agus Tripayana I Nengah, “Tradisi Magibung di Desa Pakraman Seraya, Kecamatan Karangasem, Kabupaten Karangasem, Dilihat Dari Kajian Sosio-Budaya dan Religius", S.Pd Thesis, Civic Education, Universitas Pendidikan Ganesha, 2014.

Agustian, Ary Ginanjar.(2001). Rahasia Sukses Membangun Kecerdasan Emosi dan Spiritual- ESQ, Jakarta: Penerbit Arga.

Bredemeier, B.L. \& Shields, D. L. 2019. Social Justice, Character Education, and Sport: A Position Statement. Quest, vol. 71, no. 2, pp. 202-214.

KBBI, 2016. Kamus Besar Bahasa Indonesia (KBBI). [Online] Available at: https://kbbi.kemdikbud.go.id/entri/tradisi

Lickona, Thomas. (1991). Educating for Character: How Our School Can Teach Respect and Responsibility. New York, Toronto, London, Sydney, Aucland: Bantam books.

Marini, A., Safitri, D., \& Muda, I. 2018. Managing School Based on Character Building in The Context of Religious School Culture (Case in Indonesia). Journal of Social Studies Education Research, vol. 9, no. 4, pp. 274-294.

Maris, I Nengah, dkk. (1994). Gibungan Lombok. Mataram: Parisadha Hindu Dharma Indonesia Provinsi Nusa tenggara Barat.

Miles, M.B.\& Huberman, A.M. 1992, Analisis data kualitatif: buku sumber tentang metode-metode baru. Terjemahan oleh Tjetjep Rohendi Rohidi dari judul Qualitative Data Analysis. Jakarta: Univesrsitas Indonesia Press.

Mufidah, Nastiti. 2016. Program Jam Wajib Belajar Dalam Membentuk Civic Disposition Warga Negara. Humanika, Vol. 23, No. 1, pp. 32-45

Mulyasa. 2014. Manajemen Pendidikan Karakter. Jakarta: Bumi Aksara.

Nugroho, Muhammad Aji. 2016. Pendidikan Islam Berwawasan Multikultural; Sebuah Upaya Membangun Pemahaman Keberagamaan Inklusif pada Umat Muslim dalam Mudarrisa Jurnal Kajian Pendidikan Islam. Vol. 8. No. 1. Juni. UIN Walisongo Semarang.

Piotr Sztompka. (2004). Sosiologi Perubahan Sosial. Jakarta: Prenada Media Grup

Saidek, A. R., R. Islami, \& Abdoludin. (2016). Character Issues: Reality Character Problems and Solutions through Education in Indonesia. Journal of Education and Practice, 7(17): 158-165. 
Seken (2014). Reaktualisasi Nilai Filosofi Dewata Nawa Sanga dalam Tradisi Magibung di Karangasem (Tinjauan Historis, Upacara, dan Tattwa). Amlapura: STKIP Agama Hindu Amlapura. 